\title{
Interactive comment on "Alluvial record of an early Eocene hyperthermal, Castissent Formation, Pyrenees, Spain” by Louis Honegger et al.
}

Louis Honegger et al.

louis.honegger@unige.ch

Received and published: 7 November 2019

The comment was uploaded in the form of a supplement:

https://www.clim-past-discuss.net/cp-2019-88/cp-2019-88-AC1-supplement.pdf

Interactive comment on Clim. Past Discuss., https://doi.org/10.5194/cp-2019-88, 2019. 